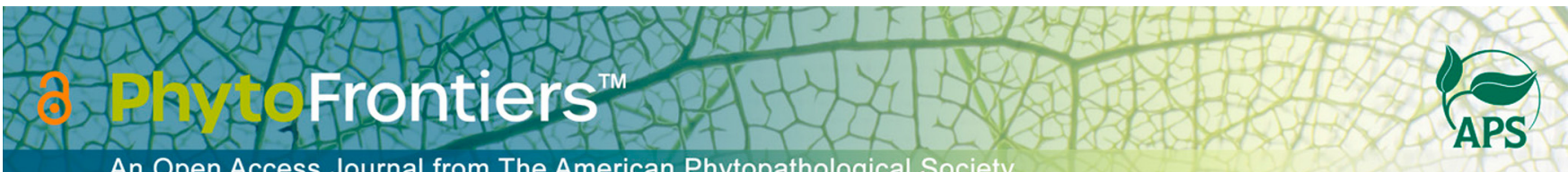

\title{
Research
}

\section{Automated Ribosomal Intergenic Spacer Analysis to Detect Pathogenic Fungi in Dark-Colored Spots on Apple Fruits}

\author{
Hiromitsu Furuya ${ }^{1,^{+}}$(D) | Yutaka Sato ${ }^{2}$ | Chiharu Nara ${ }^{1}$ | Shin-ichi Fuji ${ }^{1}$ | Takeshi Toda1(D |
}

1 Faculty of Bioresource Sciences, Akita Prefectural University, Shimo-shinjo, Akita-shi, Akita 010-0195, Japan

${ }^{2}$ Agriculture and Forestry Department, Akita Prefectural Kazuno Regional Development Bureau, Hanawa, Kazuno-shi, Akita 018-5201, Japan

† Corresponding author: H. Furuya; furuya@akita-pu.ac.jp

Accepted for publication 28 October 2021.

H. Furuya and Y. Sato contributed equally to this work.

\section{Funding}

This work was supported by the Undergraduate Student Research Funding Program 2018-2020, Faculty of Bioresource Sciences, Akita Prefectural University.

$e$-Xtra: Supplementary figures are published online.

The author(s) declare no conflict of interest.

\begin{abstract}
Dark-colored spots (DCSs) found on apples at harvest time worldwide significantly reduce the commercial value of the fruits. In this study, we conducted an automated ribosomal intergenic spacer analysis (ARISA) to reliably detect fungal pathogens in these lesions. The fragment sizes of peaks for eight species and two species complexes that might cause DCSs on apples in northern Honshu Island, Japan, were determined on the basis of the ARISA. The fragment sizes for six species (Botryosphaeria kuwatsukai, Diplocarpon mali, Mycosphaerella pomi, Neonectria galligena, Phlyctema vagabunda, and Venturia inaequalis) were unique, enabling their detection in a single ARISA trial. However, two other species and two species complexes had similar fragment sizes. To identify these fungi, PCR amplifications using species- or genus-specific primers were needed. Using this method to examine the fresh tissue of DCSs (i.e., after removing the epidermis) on commercially produced apples resulted in the detection of six fungal species and two Colletotrichum species complexes. Because the pathogenic fungi in the tissue underlying lesions are most likely the causal agents, these fungi could be responsible for the DCSs on apple fruits. An automated analysis of the PCR products amplified for the ARISA enables the rapid examination of many samples. These results indicate that the ARISA-based technique developed in the present study is useful for the accurate, reliable, and comprehensive detection of the pathogens causing DCSs on apple fruits.
\end{abstract}

Keywords: apple, automated ribosomal intergenic spacer analysis, dark-colored spots (DCSs), detection, fungal pathogen, postharvest diseases

Many airborne pathogenic fungi of apple (Malus $\times$ domestica) infect fruits as well as leaves, branches, and trunks. Small lesions at early developmental stages caused by these pathogens are often found at harvest time (Giraud and Bompeix 2012; Sutton et al. 2014). These lesions not only significantly decrease the commercial value of apples but also serve as inocula for postharvest diseases during storage and transport if they are overlooked (Wenneker 2019). The lesions, called dark-colored spots (DCSs), are 
circular or subcircular, dark brown to black, and most are less than $5 \mathrm{~mm}$ in diameter (Fig. 1).

Apple fruits with DCSs at harvest time are found in many orchards worldwide (Giraud and Bompeix 2012; Moggia and Yuri 2003; Sutton et al. 2014; Wenneker 2019). According to a survey conducted by the Department of Agriculture and Forestry of Akita Prefecture, Japan, in 2011, apple fruits with DCSs were found in virtually every orchard in southern Akita Prefecture. This major apple-growing region in Japan has 1,000.5 ha of apple orchards, including 600.5 ha used for the production of Fuji apples; this information was obtained from the Horticulture Promotion Division, Department of Agriculture, Forestry and Fisheries, Akita Prefectural Government. The damaged fruits, which were sorted as a lower-grade product, were not sold as fresh apples but were used for food processing (Narita 2005) or discarded if they were badly damaged. To prevent such damage, DCS development must be controlled following an accurate diagnosis before apples are harvested, but this is not currently done.

The infectious diseases that might cause DCS development in northern Honshu Island, Japan, include bitter rot caused by the Colletotrichum gloeosporioides species complex or the Colletotrichum acutatum species complex, Botryosphaeria rot caused by Botryosphaeria dothidea (Moug.) Ces. \& De Not. and Botryosphaeria kuwatsukai (Hara) G.Y. Sun \& E. Tanaka, Marssonina blotch caused by Diplocarpon mali Y. Harada and Sawamura [ana. Marssonina coronaria (Ellis \& Davis) Davis, syn. Ma. mali (Henn.) Ito], apple scab caused by Venturia inaequalis (Cooke) G. Winter, Brooks fruit spot caused by Mycosphaerella pomi (Pass.) Lindau, and Alternaria blotch caused by Alternaria mali Roberts. Additionally, Sato et al. (2021) recently reported that Phlyctema vagabunda Desm (syn. Neofabraea alba EJ. Guthrie.), a causal fungus of bull's-eye rot (Chen et al. 2016), causes DCSs. Other studies proved that DCSs are also caused by physiological disorders, such as lenticel blotch pit (Casero et al. 2009), lenticel spot (Brook 1968), and lenticel breakdown (Singh et al. 2016), as well as foliar disease-associated pathogens.

Traditional diagnostic techniques for DCSs, such as visual and microscopic examinations, are not effective because there is a lack of distinct characteristics associated with each disease, including spores on lesions, which are seldom detected during the early infection stages (Sutton et al. 2014; Wenneker 2019). It is therefore common to wait for several weeks, or even a few months, for typical symptoms to appear. If fast and reliable techniques for identifying pathogens are available, then the causal agent of DCSs on apples in each orchard or region can be determined, thereby enabling targeted control measures to be implemented in the following season. Moreover, accurate detection of the causal agent of DCSs is crucial for international export and import because several apple-associated pathogenic fungi are subjected to quarantine regulations in many countries.

In the last two decades, many molecular techniques have been developed to detect the causal fungi of these diseases (Gariepy et al. 2003; Michalecka et al. 2016; Skidar et al. 2014; Wenneker et al. 2017). These techniques can specifically detect a single species or the species of a single genus (Gariepy et al. 2003; Michalecka et al. 2016). To detect pathogens in lesions such as DCSs, which have a range of potential causal agents, a comprehensive technique is required. In the present study, on the basis of the automated ribosomal intergenic spacer analysis (ARISA), we developed a fast, reliable, and comprehensive technique to detect the pathogenic fungi causing DCSs on apple fruits.

The ARISA was first introduced by Fisher and Triplett (1999) to investigate freshwater bacterial diversity and community compositions. Since then, it has been extensively used for bacterial
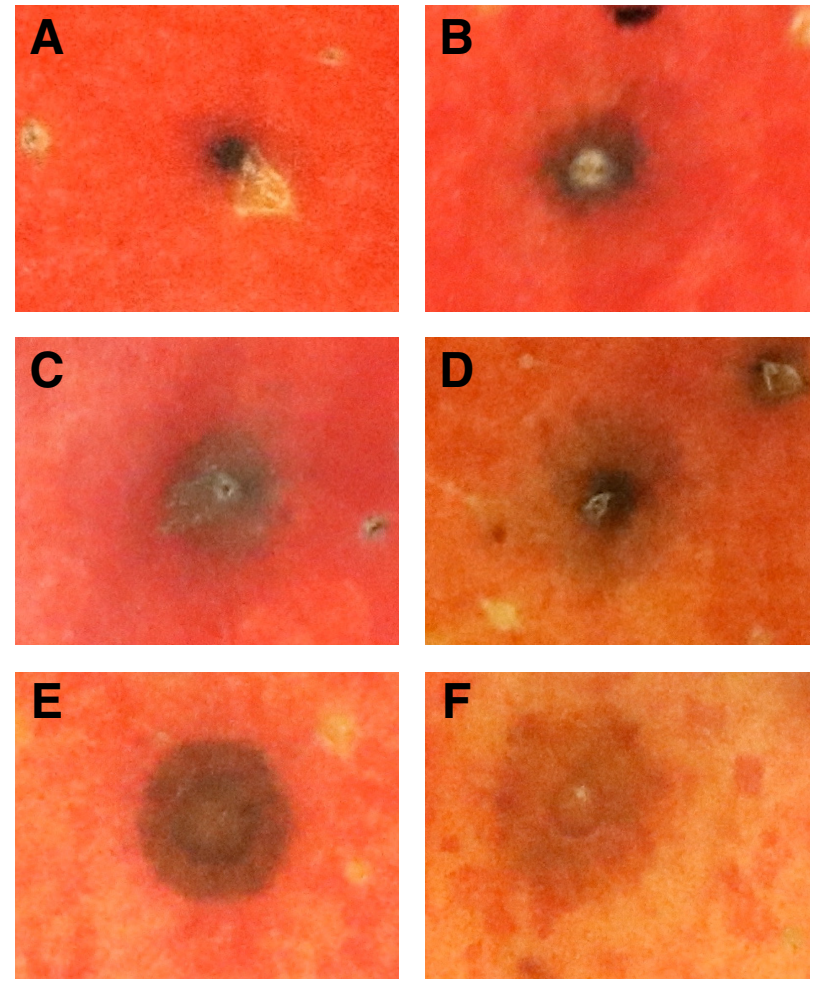

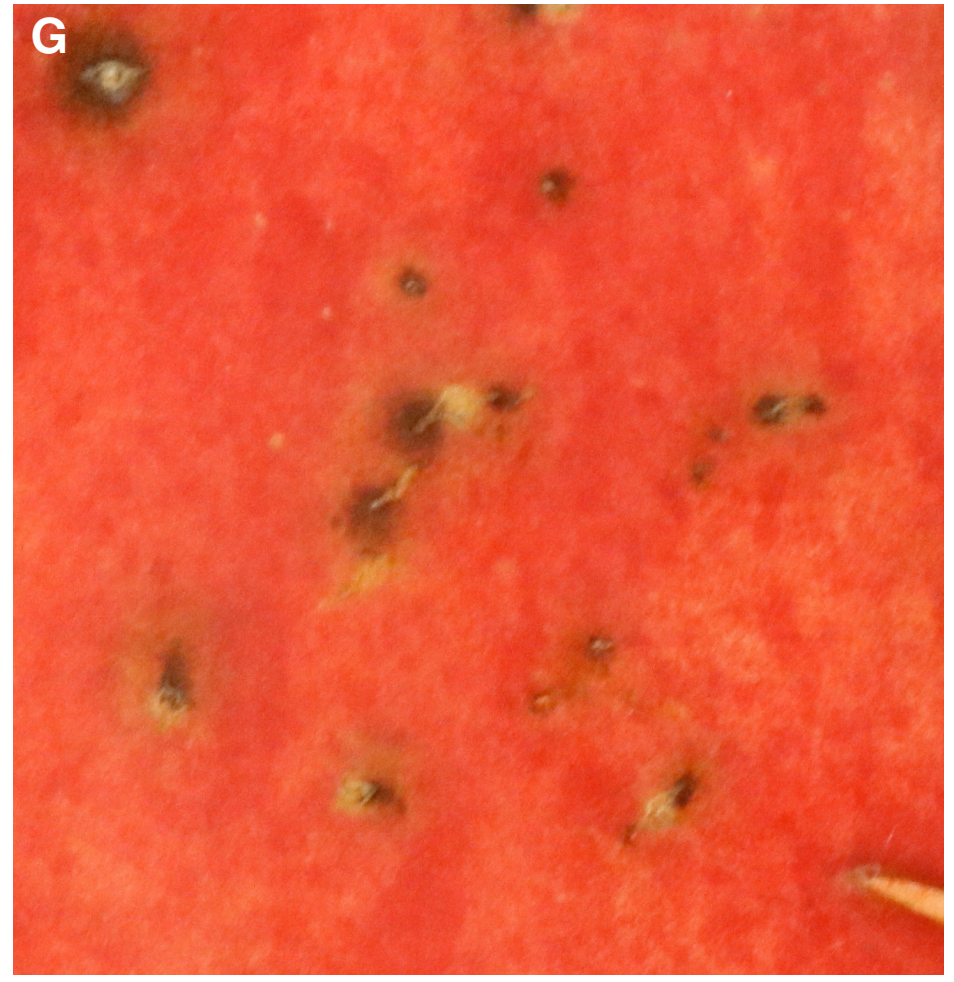

$-2$

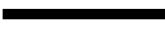

FIGURE 1

Examples of dark-colored spots (DCSs) found on Fuji apple fruits during several weeks after harvest. Botryosphaeria dothidea,

Phlyctema vagabunda, and Diplocarpon mali were detected in lesions $\mathbf{A}$ and $\mathbf{B} ; \mathbf{E}, \mathbf{F}$, and $\mathbf{G}$; and $\mathbf{D}$, respectively. $\mathbf{C}$ was not examined.

Bar indicates $5 \mathrm{~mm}$. 
community analyses of a variety of habitats, such as soils (Lerner et al. 2006; Ranjard et al. 2001), decomposing organic materials (Ciesielski et al. 2013), aquatic environments (Danovaro et al. 2006), and the mammalian gut (Jami et al. 2014). Ranjard et al. (2001) adopted the method to characterize fungal communities, using length polymorphisms of the nuclear ribosomal DNA region, which contains two internal transcribed spacer regions and the 5.85 rRNA gene. This method involves the PCR amplification of the rRNA intergenic spacer region, which may encode tRNAs. The fluorescently labeled and amplified DNA fragments can be separated and sized using a capillary electrophoresis system. These amplified fragments are denatured with formamide, and the capillary is maintained at a consistent temperature so that highly reproducible results are generated by the genetic analyzer (Fisher and Triplett 1999; Ranjard et al. 2001). The program output is a series of peaks (i.e., an electropherogram). The peaks represent fragments of varying sizes. The size of each peak is determined according to a relative comparison of the migration speeds during electrophoresis involving a size-standard peak. Fisher and Triplett (1999) observed that peaks differing in size by one base can be easily separated; this was subsequently confirmed by Ranjard et al. (2001). The peak height reflects the relative proportion of the fragments in the total product. The heterogeneity of the amplified fragment lengths and nucleotide sequences allow bacterial and fungal species to be distinguished. Each taxon, mostly at the species level, has a unique fragment size. Thus, the taxon, often at the species level, can be assumed according to the fragment size. Ikeda et al. (2007) successfully used an ARISA to efficiently detect plant pathogenic fungi at a high resolution and sensitivity in infected milled rice grain tissues. Furthermore, Pancher et al. (2012) used an ARISA to detect pathogenic fungi and to elucidate fungal endophytic communities in grapevine stems.

The aim of this study was to develop an ARISA-based technique to detect fungal pathogens in apple fruit DCSs. To the best of our knowledge, this is the first report of an ARISA being used to comprehensively detect pathogenic fungi in plant lesions.

\section{MATERIALS AND METHODS}

\section{Collection of DCS samples}

In this study, the DCSs used for the ARISA were obtained from Fuji apple fruits. The fruits with DCSs were collected from trees in an orchard at the Akita Fruit-Tree Experiment Station (latitude: 39.242475; longitude: 140.530043) that had not been sprayed with either fungicides or insecticides for many years and at regional fruit-sorting facilities in the Sakae, Masuda, and Daigo districts of Yokote City. Samples were collected from the second half of November, which is the normal harvest time in these regions, to March from 2017 to 2021 . One to seven DCSs were obtained from each fruit. The whole tissue of each DCS, including the epidermis and the underlying fresh tissue, mostly less than $5 \mathrm{~mm}$ in diameter and $3 \mathrm{~mm}$ deep, respectively, and the fresh tissue that was obtained after removing the epidermis were used. The epidermis and fresh tissue from a DCS were excised soon after the fruit was collected. Tissues were excised using a sterilized knife, placed into $2-\mathrm{ml}$ plastic tubes, and stored at $4{ }^{\circ} \mathrm{C}$ in a refrigerator. Genomic DNA was extracted from these tissues within 1 week of storage.

\section{DNA extraction from the fresh tissue or whole tissue of DCSs or fungal mycelia}

Total genomic DNA was extracted from apple fruit tissues with DCSs using the DNeasy Plant Mini Kit (Qiagen, Hilden,
Germany). Tissue segments (50 to $100 \mathrm{mg}$ ) derived from each DCS were placed in 2-ml tubes. After adding a metal cone, the tubes were placed in liquid nitrogen. The frozen tissue segments were ground in a Multi-beads shocker (Yasui Kikai Corporation, Osaka, Japan) before the DNA extraction.

Genomic DNA was also extracted from the fungal isolates obtained from DCSs using the commercial kit. Isolates were grown in 6-cm-diameter Petri dishes containing $5 \mathrm{ml}$ of potato dextrose broth at $25^{\circ} \mathrm{C}$ for 2 to 3 days in the dark. Mycelial mats were harvested by filtration, rinsed with sterile distilled water, blotted dry, placed in 2-ml tubes containing zirconia beads (Sarstedt K.K., Tokyo, Japan), ground using a BugCrasher GM-01 (Taitech, Koshigaya-shi, Saitama, Japan), and used for the DNA extraction. When storage was necessary, the mycelial mats were transferred to 2-ml tubes and stored at $-30^{\circ} \mathrm{C}$ until used.

\section{ARISA}

The DNA samples extracted from apple fruit tissues or fungal isolates were subjected to an ARISA. First, a PCR using the primer set $1406 f\left(5^{\prime}\right.$-TGYACACACCGCCCGT-3')/3126T (5'-ATATGCTTAAGTTCAGCGGGT-3') and 3126T (Hansgate et al. 2005) labeled with the fluorescent dye VIC (Applied Biosystems, Foster City, CA, U.S.A.) at the $5^{\prime}$ end was conducted to amplify the region containing partial small subunits at the $3^{\prime}$ end of the $18 \mathrm{~S}$ ribosomal DNA sequence, two internal transcribed spacers, and the 5.8S rDNA sequence of the fungal isolates obtained from apples. The PCR mixture was prepared in $0.2-\mathrm{ml}$ microtubes, each containing $20 \mu \mathrm{l}$ of reaction mixture with $1 \mathrm{ng}$ of template DNA, $200 \mu \mathrm{M}$ of dNTP mixture, $0.2 \mu \mathrm{M}$ of primer 1406f, $0.1 \mu \mathrm{M}$ of primer 3126T and fluorescent 3126T, $1 \times$ PCR buffer, and $0.05 \mathrm{U} / \mu \mathrm{l}$ of AmpliTaq Gold DNA polymerase (Applied Biosystems). The PCR amplification was completed using a DNA thermal cycler (TaKaRa PCR Thermal Cycler Dice Standard; TaKaRa Bio, Ohtsu, Shiga, Japan), with the following program: 1 cycle of $10 \mathrm{~min}$ at $95^{\circ} \mathrm{C}, 35$ cycles of $1 \mathrm{~min}$ at $95^{\circ} \mathrm{C}, 1 \mathrm{~min}$ at $55^{\circ} \mathrm{C}$, and $3 \mathrm{~min}$ at $72^{\circ} \mathrm{C}$, followed by $1 \mathrm{cy}-$ cle of $10 \mathrm{~min}$ at $72^{\circ} \mathrm{C}$. The amplified products $(4 \mathrm{ml}$ of PCR product and $1 \mathrm{ml}$ of loading dye) were analyzed by $2 \%$ agarose gel electrophoresis using Tris-acetate-EDTA buffer. The agarose gels were stained with ethidium bromide $(10 \mathrm{mg} / \mathrm{ml})$ and visualized under UV transillumination. The success of a PCR run was confirmed based on the presence or absence of fragments amplified from the DNA of P. vagabunda isolate AITC-KH54. After the confirmation of the amplified fragments, $1 \mu \mathrm{l}$ of unpurified PCR product was mixed with $0.15 \mu$ l of GeneScan 1200 LIZ Size Standard (Applied Biosystems) and $9.85 \mu \mathrm{l}$ of Hi-Di Formamide (Applied Biosystems) and then centrifuged at $140 \times g$ for $30 \mathrm{~s}$ at $20^{\circ} \mathrm{C}$ (Hitachi CF16RX II, Koki Holdings, Hitachi-shi, Ibaraki, Japan). The fragment sizes of the fluorescent PCR products and their fluorescence intensity levels (fluorescence units) were determined using an ABI 3700 Genetic Analyzer (Applied Biosystems). The analysis was conducted by Biotechnology Center, Faculty of Bioresource Sciences, Akita Prefectural University. Peaks with fragment sizes less than 600 bases were ignored because the fragments of most fungi, including every pathogenic fungus examined in this study, are estimated to contain more than 600 bases according to the GenBank database. Peaks with fluorescence intensities of less than 50 units were also ignored because they were considered unreliable. To determine the extent of the variation in fragment sizes among genetic analyzer runs, DNA extracted from cultured $P$. vagabunda AITC-KH54 mycelia was used in each ARISA trial as a positive control for the PCR amplification and a standard fragment with a known sequence length. 


\section{PCR with specific primers}

The DNA extracted from DCS tissues or fungal isolates was amplified by PCR using pathogenic fungi-specific primers. The PCR mixture was prepared in 0.2-ml microtubes, each containing $20 \mu \mathrm{l}$ of reaction mixture with $1 \mathrm{ng}$ of template DNA, $200 \mu \mathrm{M}$ of dNTP mixture, $0.1 \mathrm{mg} / \mathrm{ml}$ of bovine serum albumin, $0.2 \mu \mathrm{M}$ of primer pair, $1 \times$ PCR buffer, and $0.05 \mathrm{U} / \mu \mathrm{l}$ of AmpliTaq Gold DNA polymerase (Applied Biosystems). The PCR amplification was completed using a DNA thermal cycler (TaKaRa PCR Thermal Cycler Dice Standard), with the following program: 1 cycle of $10 \mathrm{~min}$ at $95^{\circ} \mathrm{C}, 35$ cycles of $1 \mathrm{~min}$ at $95^{\circ} \mathrm{C}, 1 \mathrm{~min}$ at $55^{\circ} \mathrm{C}$, and $3 \mathrm{~min}$ at $72^{\circ} \mathrm{C}$, followed by 1 cycle of $7 \mathrm{~min}$ at $72^{\circ} \mathrm{C}$. The following species- or genus-specific primers were used: Coll1F/3Rb (AACCWGCGGAGGGATCATTA/ TCCCTBCGRRTCCCRRTGCG) for Colletotrichum (Mosca et al. 2014), FaF/Bt2b (CATCCGCAGCGTGGGAGAACAT/ ACCCTCAGTGTAGTGACCCTTGGC) for B. dothidea (Xu et al. 2016), LinF1/LinR (TATCGCCTGGCCACCTACGC/ TGGCCACGACAACCCACATA) for A. alternata (A. mali) (Johnson et al. 2000), and MC forward/MC reverse (GCCTACCCTACCTCTGTTGC/CAGAACCAAGAGATCCGTTGTTG) for D. mali (Oberhänsli et al. 2014). The products of the amplification using the genus-specific primers Coll1F/Coll3Rb were diluted 100-fold with sterile distilled water, after which $1 \mu \mathrm{l}$ of the diluted amplified products was used as the template for additional amplifications using the PCR mixtures and PCR program described above. The amplified products were analyzed by $2 \%$ agarose gel electrophoresis as previously described. The success of the PCR was confirmed based on the presence or absence of fragments amplified from the DNA of each fungal isolate for which the species- or genus-specific primer set was designed.

\section{Sequencing of amplified products for molecular species identification}

The amplified products corresponding to the ARISA peaks were sequenced. First, the amplified products were fractionated by $2 \%$ agarose gel electrophoresis, and each fragment was excised from the gel with a sterilized razor blade. These single fragments were transferred to a $1.5-\mathrm{ml}$ tube and then purified using a GFX PCR DNA and Gel Band Purification Kit (GE Healthcare UK Limited, Buckinghamshire, U.K.). Purified DNA fragments were then sequenced using primers $1406 f$ and 3126T, the Ready Reaction Cycle Sequencing Kit (Applied Biosystems), and the ABI 3700 DNA sequencer (Applied Biosystems). The raw sequencing data were verified using 4Peaks (version 1.7) (http://staden.sourceforge.net/). The forward and reverse sequences were assembled using GENETYX-Mac (version 20) (Genetyx Science, Tokyo, Japan). Finally, the sequence data were used for a BLAST search of the GenBank database (National Center for Biotechnology Information) to identify the closest taxon. This analysis was conducted for peaks with high fluorescence intensity levels (ideally greater than 1,000) and target amplicons that were separated enough to be excised without contamination.

\section{RESULTS}

\section{Fragment sizes of pathogenic fungi in DCSs on apples}

The fragment sizes determined on the basis of an ARISA of DNA samples derived from each representative isolate of 13 pathogenic species that could be involved in the regional DCS incidence were examined in three separate tests (Table 1). The fragment size of each representative isolate of six species $(M$. pomi, Neonectria galligena, P. vagabunda, D. mali, V. inaequalis, and B. kuwatsukai) was unique among the 13 tested species and differed from the fragment sizes of other representative isolates by four or more bases. The sizes of the fragments of the remaining seven species were within three bases of the fragments from one or more other species in each trial. These species were divided into two groups, one consisting of four species with fragment sizes of 689 to 692 bases and another consisting of three species with fragment sizes of 697 to 702 bases. The former included three Colletotrichum species that belong to the $C$. gloeosporioides species complex as well as A. mali. The latter included two Colletotrichum species that belong to the $C$. acutatum species complex as well as $B$. dothidea. During three runs of the genetic analyzer, the fragment sizes of the peaks varied by up to two bases for the DNA samples of the authentic isolates of 11 pathogenic fungi, whereas they varied by three or four bases for the DNA samples of $V$. inaequalis and B. kuwatsukai (Table 1). The size of the amplified product for each pathogen was examined after sequencing the products (Table 1). The amplified products had 17 to 31 less bases than the fragments of each pathogen estimated by the ARISA.

\section{ARISA of DCS tissues}

Eight ARISA trials were conducted using DNA samples extracted from the underlying fresh tissue or from the whole tissue of 490 DCSs. The fragment size of the standard DNA sample obtained from the $P$. vagabunda isolate was between 667 and 669 bases, depending on the genetic analyzer run (Table 2). Of the tested DCSs, 452 (92\%) had one or more peaks, whereas the others had no peaks. The most common peaks were those with fragments comprising 667 to 671 bases. They were detected in $68.4 \%$ of the DNA samples obtained from DCSs analyzed. More specifically, they were detected in $69.5 \%$ and $67.6 \%$ of the DNA samples from fresh and whole tissues, respectively, as well as in $74.1 \%$ of the DNA samples in which one or more peaks were detected. A BLAST search revealed that sequences of the amplified DNA products corresponding to these peaks showed high identities to $P$. vagabunda (Table 3).

\section{ARISA of the fresh tissue from DCSs}

An ARISA was conducted using DNA samples extracted from the fresh tissue of 197 DCSs obtained from fruits collected at a non-chemically sprayed orchard and three fruit-sorting facilities (Table 2). In total, 154 (78.2\%) of the DNA samples obtained from the DCSs had a single peak, $10(5.1 \%)$ had multiple peaks, and $33(16.8 \%)$ had no peaks.

The second most common peaks among the DNA samples obtained from fresh tissues had fragments comprising 686 to 687 bases. The sequences of the amplicons corresponding to these peaks showed high identities to D. mali (ana. Ma. coronaria) (Table 3). Sequences of the amplicons corresponding to the peak with a fragment size of 1,096 bases obtained in trial No. 2 showed $99.8 \%$ identity to Botryosphaeria sp. sequences. The sequences of the amplicons corresponding to the peaks with fragment sizes of 702 bases in trial No. 1 and 697 and 699 bases in trial No. 3 showed $100 \%$ identity to Aureobasidium spp. or Penicillium sp., $96 \%$ to $99 \%$ identities to B. dothidea, and $100 \%$ identity to Colletotrichum spp., respectively.

To summarize, on the basis of an ARISA combined with a PCR using specific primers, a single pathogenic fungus was detected in 
156 of 164 DCSs $(95.1 \%)$. One or more peaks were detected for the DNA samples extracted from these 164 DCSs. Saprophytic fungi were detected in only four of these samples. The other fungi were unidentified. Of the 156 samples in which pathogenic fungi were detected, 151 had a single ARISA peak. A single pathogenic fungus was detected in five samples in which multiple peaks were detected. Thus, the causal pathogen of each DCS was determined for $79.2 \%$ of the 197 examined samples.

\section{ARISA of the whole tissue from DCSs}

An ARISA was conducted using DNA samples extracted from the whole tissue of 293 DCSs obtained from 275 apple fruits (Table 2). In total, $71.7 \%$ of the DNA samples had a single peak, $26.6 \%$ had multiple peaks, and $1.7 \%$ had no peaks. A single peak was detected for $72.9 \%$ of the DNA samples that had one or more peaks. Peaks with a fragment size of 667 to 671 bases were the most common, detected in $67.6 \%$ of the examined DCSs, followed by peaks with fragment sizes of 699 to 703 (21.2\%), 689 to $693(11.9 \%), 685$ to $686(5.5 \%)$, and 658 to $660(4.1 \%)$ bases. The sequences of the amplicons corresponding to the peaks with fragment sizes of 685 to 686 and 658 to 660 bases showed high identities to D. mali and Neonectria sp. sequences, respectively (Table 3).

Peaks with a fragment size of 699 to 703 bases were detected in 62 DCSs $(21.2 \%$ of the examined DCSs). The sequences corresponding to these peaks showed high identities to either Aureobasidium spp. or species of $C$. acutatum species complexes (Table 3). Forty-five DNA samples with peaks in this range were analyzed by PCR using B. dothidea- or Colletotrichum-specific primers. The former and latter primers amplified nine and four DNA samples, respectively (Supplementary Fig. S1).

Peaks with a fragment size of 689 to 693 bases were detected in 35 DCSs (11.9\% of the examined DCSs). The sequences associated with these peaks showed high identities to either $\mathrm{Al}$ ternaria spp. or species of the C. gloeosporioides species complex (Table 3). Thirty-three DNA samples with peaks in this range were subjected to a PCR analysis using A. alternata (A. mali)and Colletotrichum-specific primers. The former primers did not amplify any DNA samples, whereas the latter primers amplified six DNA samples (Supplementary Fig. S2).

All pathogenic fungi described in this section were isolated from DCSs on apple fruits in the present study.

\section{DISCUSSION}

The fragment sizes of the ARISA peaks for the authentic isolates of six fungal species (B. kuwatsukai, D. mali, M. pomi, Ne. galligena, $P$. vagabunda, and $V$. inaequalis) differed by four or more bases from the fragments of the other analyzed species (Table 1) potentially involved in the DCS development on apple fruits in northern Honshu Island, Japan. Because peaks with fragments differing in size by one base can be separated by this analysis (Fisher and Triplett 1999; Ranjard et al. 2001), the four-base differences are sufficient for detecting the peaks corresponding to specific fungi. Thus, these six species can be identified in a single ARISA trial. In fact, when the ARISA was used to detect pathogens in the DCSs on commercially produced apple fruits in the present study, peaks with fragment sizes corresponding to five of these six species were detected (i.e., B. kuwatsukai, D. mali, Ne. galligena, P. vagabunda, and V. inaequalis; Table 2). The identification of these peaks was confirmed by a BLAST search using the sequence data of the amplicons corresponding to the peaks (Table 3). This confirmation eliminates the need for more traditional diagnostic methods for analyzing DCSs on commercially produced apple fruits.

The fragment sizes of the ARISA peaks for the authentic isolates of four other taxa were not discriminative. However, the ARISA results indicated which primers should be used for the subsequent PCR-based species identification. More specifically, when peaks with fragment sizes of approximately 690 bases were detected, A. mali- or Colletotrichum-specific primers were used. In contrast, when peaks with fragment sizes of about 700 bases were detected, B. dothidea- or Colletotrichum-specific primers were used. This method can detect pathogens in DCSs more efficiently (i.e., in terms of time and cost) than other fingerprinting techniques, including PCR amplifications using species-specific primers without any reasonable hypothesis regarding the target fungus.

Before 2012, apple bitter rot in Japan was considered to be caused by $C$. acutatum J. H. Simmonds and $C$. gloeosporioides (Penz.) Penz. \& Sacc. (Kawai et al. 2000; Sato and Moriwaki 2009; Tsushima and Yukita 2002). On the basis of the information regarding the multigene sequence-based taxonomy of the genus, two species complexes (i.e., C. acutatum species complex and $C$. gloeosporioides species complex) were proposed in 2012 , with many new species in each species complex (Cannon et al. 2012; Damm et al. 2012). Since then, several species have been

\section{TABLE 1}

Fragment sizes of major polymerase chain reaction products (peaks) assessed by genetic analyzer in automated ribosomal intergenic spacer analysis (ARISA) with DNA samples of pathogenic fungi that might be involved in the formation of dark-colored spots (DCSs) on apple fruits in Yokote region, Akita

\begin{tabular}{|c|c|c|c|c|c|c|}
\hline \multirow[b]{2}{*}{ Taxon } & \multirow[b]{2}{*}{ Isolate no. } & \multirow[b]{2}{*}{ Disease } & \multirow[b]{2}{*}{ No. of $b^{a}$} & \multicolumn{3}{|c|}{ Fragment sizes in ARISA } \\
\hline & & & & Trial 1 & Trial 2 & Trial 3 \\
\hline Mycosphaerella pomi & MAFF 645022 & Brooks fruit spot & 627 & 652 & 650 & 650 \\
\hline Neonectria galligena & MAFF 410257 & Nectria canker & 635 & 659 & 658 & - \\
\hline Phlyctema vagabunda & AITC KH54 & Bull's-eye rot & 639 & 667 & - & 668 \\
\hline Diplocarpon mali & MAFF 645015 & Marssonina blotch & 659 & 686 & 685 & 685 \\
\hline Colletotrichum aenigma & MAFF 244310 & Bitter rot & 664 & 690 & 689 & 689 \\
\hline C. siamense & MAFF 244307 & Bitter rot & 664 & 691 & 691 & 691 \\
\hline C. fructicola & MAFF 244311 & Bitter rot & 665 & 691 & 692 & 692 \\
\hline Alternaria mali & HBA1 & Alternaria blotch & 661 & 692 & - & - \\
\hline C. fioriniae & MAFF 306630 & Bitter rot & 674 & 699 & 702 & 702 \\
\hline Botryosphaeria dothidea & $25-192 \mathrm{~A}$ & Botryosphaeria rot & 673 & 698 & 700 & 698 \\
\hline C. nymphaeae & MAFF 306546 & Bitter rot & 674 & 701 & 700 & 701 \\
\hline Venturia inaequalis & MAFF 237305 & Apple scab & 1,029 & 1,046 & 1,042 & 1,044 \\
\hline B. kuwatsukai & YTK-1 & White rot & 1,072 & 1,095 & 1,096 & 1,097 \\
\hline
\end{tabular}

a The numbers were calculated based on sequence data of each pathogen. 
reported as the causal agents of apple bitter rot (Misawa and Sato 2013; Phytopathological Society of Japan 2021; Yokozawa et al. 2017). Basic disease control measures, however, need not be altered depending on the species in each species complex (Akahira et al. 2016; Iwanami et al. 2003). Thus, the species complex-level identification of causal fungi by the ARISA-based technique is useful, allowing growers to make more informed decisions regarding how to control DCS development.

A single peak was detected for most fresh tissues of DCSs. Most of these peaks were for DNA samples from pathogenic fungi. Because pathogenic fungi can infect intact host plant tissues, whereas saprophytic fungi usually cannot, a pathogenic fungus detected within the underlying tissue is most likely the causal agent of the lesion. Accordingly, the pathogenic fungus detected in the fresh tissue of DCSs could be considered the causal agent. Another benefit to using the fresh tissue of DCSs for an ARISA is that it can minimize the chances of detecting other fungi unrelated to DCS development, including saprophytic and pathogenic fungi that might have appeared by chance at the lesion surface. These fungi often interfere with the detection of causal fungi by masking the causal fungi or adversely affecting detection sensitivity. Therefore, to accurately identify the causal agents, the DNA samples used for an ARISA should be obtained from the fresh tissue of DCSs (i.e., after the epidermis is removed). A pathogenic fungus was detected in 150 of the 154 DNA sam- ples that had a single peak, clearly suggesting that fresh tissues are useful for detecting the pathogenic fungi that induce DCS development.

There are no published reports describing the isolation of Ne. galligena, which is the pathogen responsible for apple canker disease, in the study region, but it was detected on apples for the first time by an ARISA. Because this analysis is a nontargeted, multiplex fingerprinting technique, pathogenic fungi were detected on apples even though they had not been reported previously as causal agents of DCSs on apple fruits, reflecting the utility of the ARISA. There are several pathogenic fungi that cause DCSs on apples that have not been reported in Japan (Hou et al. 2019; Wenneker et al. 2017). These fungi can be detected by performing an ARISA. In the present study, Ne. galligena was detected in the whole tissue, but not in the fresh tissue, of DCSs. Consequently, whether this fungus causes DCSs remains to be confirmed.

A total of 197 DCS samples were analyzed, and the causal pathogen was determined for $79.2 \%$ of the samples by a single ARISA trial combined with a PCR amplification using specific primers. Sequencing followed by a BLAST search verified these findings. The results indicated that $P$. vagabunda, D. mali, B. dothidea, B. kuwatsukai, and Colletotrichum spp. induce DCS development and that Ne. galligena was present in Yokote Basin, Akita Prefecture.

\section{TABLE 2}

Automated ribosomal intergenic spacer analyses (ARISAs) using DNA samples extracted from fresh or whole tissues, independently, of dark-colored spots (DCSs) on apple fruits

\begin{tabular}{|c|c|c|c|c|c|c|c|c|c|}
\hline $\begin{array}{l}\text { ARISA } \\
\text { trial no. }\end{array}$ & $\begin{array}{c}\text { Apple } \\
\text { collection }\end{array}$ & $\begin{array}{c}\text { DCS } \\
\text { sampling }\end{array}$ & $\begin{array}{l}\text { No. of } \\
\text { apples }\end{array}$ & $\begin{array}{l}\text { No. of } \\
\text { DCSs } \\
\text { obtained }\end{array}$ & $\begin{array}{l}\text { No. of } \\
\text { DCSs with } \\
\text { peaks } \\
\text { detected }\end{array}$ & $\begin{array}{l}\text { Ratio of } \\
\text { DCSs with } \\
\text { a single } \\
\text { peak (\%) }\end{array}$ & $\begin{array}{l}\text { Fragment } \\
\text { sizes of } \\
\text { standard } \\
\text { DNA } \\
\text { sample }^{\mathrm{a}}\end{array}$ & $\begin{array}{l}\text { Fragment sizes of } \\
\text { peaks detected in } \\
10 \% \text { or more of } \\
\text { DCSs having } \\
\text { peaks }(\%)\end{array}$ & $\begin{array}{l}\text { Fragment sizes of peaks } \\
\text { detected less frequently } \\
\text { than } 10 \% \text { (number of } \\
\text { DCSs in which the peak } \\
\text { was detected) }\end{array}$ \\
\hline \multicolumn{10}{|c|}{ Analysis of fresh tissues } \\
\hline No. 1 & Sakae s.f. ${ }^{\text {b }}$ & 15 Dec. 2018 & 6 & 29 & 23 & 73.9 & 669 & $\begin{array}{l}669-670(87.0) \\
\quad 702-703(20.4)\end{array}$ & $\begin{array}{l}632,660,689,693,709 \\
\quad 713,711,752\end{array}$ \\
\hline No. 2 & Masuda s.f. & 9 Jan. 2019 & 26 & 26 & 20 & 95.0 & 667 & $667-668(85.0)$ & $658,1,094,1,095,1,096$ \\
\hline No. 3 & Masuda s.f. & 29 Mar. 2021 & 10 & 47 & 37 & 97.3 & 668 & $\begin{array}{l}667-669(62.2) \\
686(18.9)\end{array}$ & $681(2), 697(4), 699,761$ \\
\hline No. 3 & Daigo s.f. & 29 Mar. 2021 & 10 & 47 & 40 & 100.0 & 668 & $668-669(90.0)$ & $649,687,701,1,095$ \\
\hline No. 4 & $\begin{array}{l}\text { Nonchemical } \\
\text { sprayed } \\
\text { orchard }\end{array}$ & 29 Mar. 2021 & 10 & 48 & 44 & 95.5 & 668 & $668-669(90.9)$ & $\begin{array}{l}683,687,691,697,700 \\
\quad 749\end{array}$ \\
\hline \multicolumn{10}{|c|}{ Analysis of whole tissues } \\
\hline No. 5 & $\begin{array}{l}\text { Nonchemical } \\
\text { sprayed } \\
\text { orchard }\end{array}$ & 26 Nov. 2017 & 26 & 44 & 42 & 83.3 & 667 & $\begin{array}{l}667-668(55), \\
658-659(19), \\
700-701(15), \\
691(15)\end{array}$ & $\begin{array}{l}680,681,696(2), 709 \\
\quad 728,748,1,095\end{array}$ \\
\hline No. 6 & $\begin{array}{l}\text { Nonchemical } \\
\text { sprayed } \\
\text { orchard }\end{array}$ & $\begin{array}{l}\text { 9-10 Jan. } \\
2019\end{array}$ & 88 & 88 & 88 & 78.4 & 667 & $\begin{array}{c}667-668(36) \\
699-701(28), \\
685-686(18), \\
689-691(15)\end{array}$ & $\begin{array}{l}616,629(4), 648, \\
650-652(8), 660,665, \\
672,673,676,681, \\
694,696,705,708, \\
709,712,722,723, \\
738,1,045, \\
1,093-1,095(8)\end{array}$ \\
\hline No. 6 & Masuda s.f. & $\begin{array}{l}\text { 9-10 Jan. } \\
2019\end{array}$ & 44 & 44 & 41 & 73.2 & 667 & $\begin{array}{l}667-668(90) \\
700-701(17)\end{array}$ & $\begin{array}{l}629,658,690,691,692 \\
\quad 722,723,1,094,1,095 \\
\quad(2)\end{array}$ \\
\hline No. 7 & Sakae s.f. & 10 Jan. 2020 & 57 & 57 & 57 & 59.6 & 669 & $\begin{array}{l}668-670(83), \\
702(19), \\
690-693(19), \\
630(11)\end{array}$ & $\begin{array}{l}658,659,660,664,665 \\
674-675(5), 698(3) \\
705,709,853-854(4) \\
1,096\end{array}$ \\
\hline No. 8 & Daigo s.f. & 10 Jan. 2020 & 60 & 60 & 60 & 70.0 & 669 & $\begin{array}{l}669-671(98) \\
\quad 702-703(22)\end{array}$ & $\begin{array}{c}630(3), 652,653,675 \\
692-693(3), 708,710 \\
723,725,739,749\end{array}$ \\
\hline
\end{tabular}

\footnotetext{
a The DNA was prepared from mycelia of an isolate of Phlyctema vagabunda.

${ }^{b}$ s.f. = sorting facility.
} 
TABLE 3

Molecular identification of amplicons corresponding to peaks detected by automated ribosomal intergenic spacer analyses (ARISAs) using DNA samples extracted from fresh and whole tissues, independently, of dark-colored spots (DCSs) from Fuji apples

\begin{tabular}{|c|c|c|c|c|c|c|}
\hline $\begin{array}{l}\text { ARISA } \\
\text { trial no., } \\
\text { sample ID of DCS }\end{array}$ & $\begin{array}{l}\text { Fragment } \\
\text { sizes in } \\
\text { ARISA }\end{array}$ & $\begin{array}{l}\text { Fluorescence } \\
\text { intensity }\end{array}$ & $\begin{array}{l}\text { Determined } \\
\text { nucleotide } \\
\text { length } \\
\text { (nts) }\end{array}$ & $\begin{array}{l}\text { Nucleotide } \\
\text { sequence } \\
\text { identity } \\
(\%)\end{array}$ & E value & Closest organism (accession no.) \\
\hline \multicolumn{7}{|c|}{ Analysis of fresh tissues } \\
\hline \multicolumn{7}{|l|}{ No. 1} \\
\hline E01B & 669 & 4,442 & 116 & 95.69 & $1.00 \mathrm{E}-43$ & Phlyctema vagabunda (LC171685.1) \\
\hline E26B & 669 & 7,417 & 536 & 99.81 & 0.0 & $\begin{array}{l}\text { P. vagabunda (KT923785.1), Neofabraea alba } \\
\text { (KJ396077.1) }\end{array}$ \\
\hline E71B & 669 & 2,826 & 475 & 95.76 & $1.00 \mathrm{E}-169$ & P. vagabunda (MH855316.1), N. alba (KJ396077.1) \\
\hline E85B & 669 & 2,597 & 523 & 99.24 & 0.0 & P. vagabunda (KY367507.2), N. alba (KJ396077.1) \\
\hline $\mathrm{E} 28 \mathrm{~B}$ & 702 & 3,214 & 450 & 100 & 0.0 & $\begin{array}{l}\text { Aureobasidium pullulans (MT573468.1), Kabatiella } \\
\text { microsticta (MT107050.1), Metschnikowia sp. } \\
\text { (MG906980.1) }\end{array}$ \\
\hline E38B & 702 & 1,659 & 568 & 100 & 0.0 & $\begin{array}{l}\text { Au. pullulans (MT573468.1), Au. protea (JN712492.1), } \\
\text { Dothideomycetes sp. (FN868453.1), K. microsticta } \\
\text { (MT107050.1) }\end{array}$ \\
\hline E50B & 702 & 6,596 & 456 & 100 & 0.0 & $\begin{array}{l}\text { Penicillium corylophilum (MK450687.1), Penicillium spp. } \\
\text { (MH865722.1, MH858652.1, MH855058.1, } \\
\text { MF475914.1) }\end{array}$ \\
\hline \multicolumn{7}{|l|}{ No. 2} \\
\hline M42B & 667 & 4,461 & 535 & 99.63 & 0.0 & Identical to E26B \\
\hline M61B & 667 & 2,015 & 535 & 99.63 & 0.0 & Identical to E26B \\
\hline M64B & 667 & 3,454 & 535 & 99.63 & 0.0 & Identical to E26B \\
\hline M85B & 1,096 & 697 & 401 & 99.75 & 0.0 & $\begin{array}{l}\text { Botryosphaeria sp. (KJ80760.1), B. berengeriana } \\
\quad(\text { FJ441665.1) }\end{array}$ \\
\hline \multicolumn{7}{|r|}{$(13+4+1003.1)$} \\
\hline MF9 & 668 & 2,590 & 536 & 99.81 & 0.0 & Identical to KJA16 \\
\hline MJ1 & 668 & 2,209 & 480 & 99.79 & 0.0 & N. alba $(\mathrm{KJ} 396077.1)$ \\
\hline MM5 & 668 & 2,062 & 406 & 99.75 & 0.0 & Identical to MJ1 \\
\hline MI1 & 686 & 2,987 & 556 & 99.81 & 0.0 & Diplocarpon mali (AB609191.1) \\
\hline MI2 & 686 & 3,581 & 528 & 99.60 & 0.0 & Identical to MI1 \\
\hline ML4 & 686 & 1,582 & 490 & 100 & 0.0 & Identical to MI1 \\
\hline ML5 & 686 & 471 & 555 & 98.56 & 0.0 & Marssonina coronaria (HM368521.1) \\
\hline MM1 & 697 & 1,167 & 211 & 99.63 & $2.00 \mathrm{E}-84$ & $\begin{array}{l}\text { B. dothidea (MT611222.1), Botryosphaeria sp. } \\
\text { (MT587332.1) }\end{array}$ \\
\hline MM3 & 697 & 988 & 258 & 100 & $8.00 \mathrm{E}-124$ & Identical to MM1 \\
\hline MM4 & 697 & 707 & 325 & 96.00 & $1.00 \mathrm{E}-157$ & B. dothidea (KC527826.1) \\
\hline MG9 & 699 & 288 & 570 & 100 & 0.0 & $\begin{array}{l}\text { Colletotrichum nymphaeae (MN744277.1), C. acutatum } \\
\text { (KU933355.1), C. guajavae (KJ813590.1), } \\
\text { C. simmondsii (JN121202.1), Colletotrichum sp. } \\
\text { (LC435466.1), Glomerella acutata (AY266405.1) }\end{array}$ \\
\hline \multicolumn{7}{|r|}{ 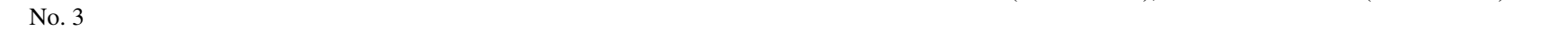 } \\
\hline DH6 & 649 & 2,567 & 411 & 99.03 & 0.0 & Ascomycota sp. (HQ166343.1) \\
\hline DI1 & 668 & 2,957 & 481 & 99.00 & 0.0 & P. vagabunda (LC171685.1a) \\
\hline DL1 & 668 & 7,023 & 535 & 100 & 0.0 & Identical to KJA16 \\
\hline DO1 & 668 & 2,500 & 535 & 100 & 0.0 & Identical to KJA16 \\
\hline \multirow{2}{*}{\multicolumn{7}{|c|}{ 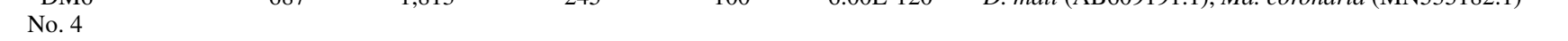 }} \\
\hline & & & & & & \\
\hline KJA16 & 668 & 3,447 & 535 & 99.63 & 0.0 & P. vagabunda (KT923785.1), N. alba (KJ396077.1) \\
\hline KJB10 & 668 & 2,742 & 326 & 100 & $3.00 \mathrm{E}-168$ & P. vagabunda (LC171685.1) \\
\hline KJG1 & 668 & 2,671 & 369 & 100 & 0.0 & Identical to KJB10 \\
\hline KJA7 & 687 & 2,739 & 452 & 100 & 0.0 & Ma. coronaria (MG984759.1) \\
\hline \multicolumn{7}{|c|}{ Analysis of whole tissues } \\
\hline \multicolumn{7}{|l|}{ No. 5} \\
\hline 17SD-A & 658 & 2,433 & 480 & 100 & 0.0 & $\begin{array}{l}\text { Neonectria galligena (JQ434582.1), Ne. major (NR } \\
\text { 121496.1), Neonectria sp. (HQ166303.1) }\end{array}$ \\
\hline 17SD-C & 658 & 4,103 & 486 & 100 & 0.0 & Identical to $17 \mathrm{SD}-\mathrm{A}$ \\
\hline $17 \mathrm{JO}-\mathrm{C}$ & 668 & 6,354 & 480 & 100 & 0.0 & P. vagabunda (KY367507.2), N. alba (KJ396077.1) \\
\hline 17JO-E & 667 & 7,360 & 529 & 99.81 & 0.0 & P. vagabunda (KT923785.1), N. alba (KJ396077.1) \\
\hline 25-1-9-P & 691 & 1,100 & 371 & 78.25 & $3.00 \mathrm{E}-77$ & Alternaria sp. (KM454902.1) \\
\hline $25-11-1$ & 691 & 2,413 & 500 & 100 & 0.0 & $\begin{array}{l}\text { Alternalia spp. (MF602685.1, MK311341.1, MK311298.1, } \\
\text { MK303973.1, MH237662.1, MG589272.1, } \\
\text { LC206592.1) }\end{array}$ \\
\hline $25-1-9-\mathrm{N}$ & 701 & 1,991 & 509 & 100 & 0.0 & $\begin{array}{l}\text { Aureobasidium spp. (MK460317.1, MK460806.1, } \\
\text { KT6925262.1), K. microsticta (MH858817.1), } \\
\text { Metschnikowia sp. (MG906980.1), Dothideomycetes sp. } \\
\text { (FN868453.1) }\end{array}$ \\
\hline S42 & 692 & 1,370 & 554 & 100 & 0.0 & $\begin{array}{l}\text { A. alternata (MN822657.1), A. tenuissima (MN559435.1), } \\
\text { A. yaliinficiens (MK659955.1), Alternaria sp. } \\
\text { (MN856304.1) }\end{array}$ \\
\hline
\end{tabular}


The fragment sizes of the peaks varied a little among the three runs of the genetic analyzer (Table 1). The fragment sizes of the peaks for the DNA sample of a $P$. vagabunda isolate, which was used as the standard sample in each trial, were between 667 and 669 bases during the eight runs of the genetic analyzer, indicative of the high reproducibility of the data (Table 2). However, considering that the fragment size of a peak for individual fungal species can vary among trials (Table 1 ), a DNA sample extracted from an authentic fungal isolate should be used as a standard to determine the fragment size variation among trials.

The analysis of the collected apple fruits revealed that $P$. vagabunda is by far the most dominant causal agent of DCSs

TABLE 3 (Continued from previous page)

\begin{tabular}{|c|c|c|c|c|c|c|}
\hline $\begin{array}{l}\text { ARISA } \\
\text { trial no., } \\
\text { sample ID of DCS }\end{array}$ & $\begin{array}{l}\text { Fragment } \\
\text { sizes in } \\
\text { ARISA }\end{array}$ & $\begin{array}{l}\text { Fluorescence } \\
\text { intensity }\end{array}$ & $\begin{array}{l}\text { Determined } \\
\text { nucleotide } \\
\text { length } \\
\text { (nts) }\end{array}$ & $\begin{array}{c}\text { Nucleotide } \\
\text { sequence } \\
\text { identity } \\
(\%)\end{array}$ & E value & Closest organism (accession no.) \\
\hline \multicolumn{7}{|c|}{ Analysis of whole tissues } \\
\hline \multicolumn{7}{|c|}{ No. 6} \\
\hline AK-20 & 667 & 1,756 & 479 & 100 & 0.0 & P. vagabunda (LC171685.1) \\
\hline AK-35 & 667 & 2,268 & 535 & 99.81 & 0.0 & P. vagabunda (KR859275.1), N. alba (KJ396077.1) \\
\hline AK-81 & 668 & 3,475 & 535 & 99.63 & 0.0 & P. vagabunda (KT923785.1) \\
\hline AK-1 & 685 & 4,346 & 248 & 96.75 & $6.00 \mathrm{E}-112$ & D. mali (AB609191.1) \\
\hline AK-2 & 686 & 7,217 & 547 & 100 & 0.0 & Identical to AK-1 \\
\hline AK-14 & 686 & 4,256 & 545 & 99.62 & 0.0 & Identical to AK-1 \\
\hline AK-30 & 686 & 3,375 & 536 & 99.81 & 0.0 & Identical to AK-1 \\
\hline AK-69 & 686 & 3,223 & 557 & 100 & 0.0 & Identical to AK-1 \\
\hline AK-74 & 686 & 4,306 & 556 & 98.20 & 0.0 & Ma. coronaria $(\mathrm{HM} 36852.1)$ \\
\hline AK-36 & 689 & 3,185 & 315 & 92.74 & $5.00 \mathrm{E}-134$ & A. tenuissima (MG569636.1), A. alternata (JQ625592.1) \\
\hline AK-45 & 689 & 745 & 422 & 97.16 & 0.0 & $\begin{array}{l}\text { C. siamense (MG751903.1), C. gloeosporioides } \\
\text { (KR704206.1) }\end{array}$ \\
\hline AK-65 & 689 & 932 & 374 & 99.73 & 0.0 & $\begin{array}{l}\text { C. siamense (MK141761.1), C. gloeosporioides } \\
\text { (KR704206.1) }\end{array}$ \\
\hline AK-94 & 689 & 1,127 & 557 & 100 & 0.0 & $\begin{array}{l}\text { C. siamense (LC260490.1), C. gloeosporioides } \\
\text { (KR704206.1) }\end{array}$ \\
\hline $\mathrm{AK}-33$ & 699 & 3,448 & 558 & 100 & 0.0 & $\begin{array}{l}\text { C. fioriniae (MN077457.1), C. acutatum (MH931266.1), } \\
\text { C. lupini (LC206489.1), G. acutata (JF288551.1), } \\
\text { G. fioriniae (JN943453.1) }\end{array}$ \\
\hline $\mathrm{AK}-40$ & 700 & 259 & 567 & 99.65 & 0.0 & $\begin{array}{l}\text { Aureobasidium spp. (MN077446.1, KX100335.1, } \\
\text { JN712492.1), K. microsticta }(\mathrm{MH} 858817.1) \\
\text { Dothideomycetes } \text { sp. (FN868453.1) }\end{array}$ \\
\hline AK-92 & 701 & 1,003 & 459 & 98.47 & 0.0 & $\begin{array}{l}\text { Aureobasidium spp. (MK937952.1, KY436128.1), } \\
\text { Kwoniella } \text { sp. (MK613238.1), K. microsticta } \\
\text { (MH858817.1), Metschnikowia } \text { sp. (MG906980.1) }\end{array}$ \\
\hline AK-47 & 1,045 & 217 & 888 & 99.32 & 0.0 & Venturia inaequalis (DQ887774.1) \\
\hline \multicolumn{7}{|l|}{ No. 6} \\
\hline M91A & 667 & 5,584 & 487 & 99.79 & 0.0 & Identical to $17 \mathrm{JO}-\mathrm{E}$ \\
\hline M59A & 668 & 3,363 & 481 & 100 & 0.0 & N. kienholzii (KR859083.1), Neofabraea sp. (KU712233.1) \\
\hline M72A & 667 & 4,375 & 487 & 100 & 0.0 & P. vagabunda (KT923785.1), N. alba (KJ396076.1) \\
\hline M65A & 692 & 471 & 557 & 100 & 0.0 & A. alternata (MH844771.1) \\
\hline \multicolumn{7}{|l|}{ No. 7} \\
\hline $\mathrm{S} 12$ & 669 & 2,325 & 536 & 99.81 & 0.0 & P. vagabunda (KT923785.1), N. alba (KJ396077.1) \\
\hline S35 & 669 & 2,128 & 535 & 100 & 0.0 & Identical to S12 \\
\hline S49 & 669 & 5,635 & 535 & 99.81 & 0.0 & Identical to $\mathrm{S} 12$ \\
\hline S55 & 669 & 2,955 & 535 & 100 & 0.0 & Identical to S12 \\
\hline $\mathrm{S} 2$ & 692 & 5,018 & 556 & 100 & 0.0 & $\begin{array}{l}\text { A. alternata (MN944587.1), A. tenuissima } \\
\quad(\mathrm{MH}-824257.1), \text { Alternaria } \mathrm{sp} .(\mathrm{MT} 035960.1)\end{array}$ \\
\hline S14 & 692 & 1,214 & 556 & 100 & 0.0 & Identical to $\mathrm{S} 2$ \\
\hline S19 & 692 & 1,122 & 556 & 99.82 & 0.0 & Identical to $\mathrm{S} 2$ \\
\hline S20 & 693 & 236 & 557 & 100 & 0.0 & $\begin{array}{l}\text { A. alternata (KY026591.1), A. tenuissima (MF405157.1), } \\
\text { A. brassicola (KF542.557.1), A. mali (AB470849.1), } \\
\text { Alternaria sp. (KT264732.1) }\end{array}$ \\
\hline $\mathrm{S} 30$ & 691 & 1,370 & 554 & 97.82 & 0.0 & A. alternata (KY026591.1) \\
\hline S32 & 693 & 1,886 & 558 & 99.82 & 0.0 & $\begin{array}{l}\text { A. alternata (KY026591.1), A. tenuissima (MF405157.1), } \\
\text { A. brassicola (KF542.557.1), Alternaria } \mathrm{sp} . \\
\text { (KJ527009.1) }\end{array}$ \\
\hline S42 & 692 & 1,370 & 554 & 100 & 0.0 & $\begin{array}{l}\text { A. alternata (MN822657.1), A. tenuissima (MN559435.1), } \\
\text { A. yaliinficiens (MK659955.1), Alternaria } \mathrm{sp.} \\
\text { (MN856304.1) }\end{array}$ \\
\hline \multicolumn{7}{|r|}{ (2) } \\
\hline D6 & 669 & 4,101 & 535 & 99.63 & 0.0 & P. vagabunda (KT923785.1), N. alba (KJ396077.1) \\
\hline D26 & 670 & 2,938 & 535 & 99.63 & 0.0 & Identical to D6 \\
\hline D35 & 670 & 4,696 & 535 & 99.81 & 0.0 & Identical to D6 \\
\hline D30 & 692 & 2,069 & 561 & 99.82 & 0.0 & $\begin{array}{l}\text { C. siamense (LC260490.1), C. gloeosporioides } \\
\quad(\text { KR704204.1) }\end{array}$ \\
\hline D11 & 702 & 661 & 902 & 99.86 & 0.0 & $\begin{array}{l}\text { Au. pullulans (MH9312627.1), K. microsticta } \\
\text { (EU167608.1) }\end{array}$ \\
\hline D46 & 703 & 1,272 & 823 & 99.86 & 0.0 & Au. protea (JN712492.1), K. microsticta (EU167608.1) \\
\hline
\end{tabular}


in the study region, but it might not be the dominant fungus in every orchard in the region. Pathogens other than $P$. vagabunda were detected in $38 \%$ of the DCSs from fruits obtained from the Masuda sorting facility in March 2021 (Table 2). Because of the automated analysis of the PCR products for an ARISA, many samples can be processed simultaneously, thereby enabling the identification of the causal agent(s) in each orchard in a particular region. This allows apple producers to adopt the most appropriate DCS control strategy for each orchard. To limit the damages caused by DCSs, accurate diagnosis at the orchard level is crucial.

ARISA is a nontargeted, multiplex fingerprinting technique that can analyze many samples at the same time.

A single ARISA trial or a single ARISA trial combined with a PCR amplification using specific primers can detect all pathogenic fungi causing DCSs (e.g., eight species and two species complexes). The ARISA-based technique can accurately, reproducibly, efficiently, and comprehensively detect the pathogens responsible for DCSs. It is clearly more useful than other DNA-based fingerprinting techniques for diagnosing DCSs in these respects. It could be applicable for other plant diseases that produce similar symptoms (Supplementary Fig. S3). Furthermore, the method could be effective for the initial screening of quarantined organisms at ports because of its sensitivity and its utility for analyzing numerous samples simultaneously for the presence of multiple pathogenic fungi (Lin et al. 2018).

Pathogenic fungi were undetectable in the fresh tissue of 33 DCSs (16.8\% of the examined DCSs). These DCSs might have resulted from physiological disorders, including bitter pit and lenticel blotch pit (Ferguson and Triggs 1990; Raese and Drake 2002). This possibility will need to be experimentally verified.

Peaks with fragment sizes of 689 to 693 and 699 to 703 bases were more frequently detected for the DNA samples obtained from the whole tissue of DCSs than for those from the fresh tissue of DCSs. Additionally, $30 \%$ and $20 \%$ of these peaks, respectively, were for DNA samples from saprophytic fungi according to the sequence analyses and PCR with specific primers. These fungi, including Alternaria spp. and Aureobasidium spp., are often present in the phyllosphere of apple orchards (Andrews et al. 2002; Woody et al. 2003). Au. pullulans is a potential biocontrol agent that could prevent postharvest diseases in pome fruits (Mari et al. 2012; Vero et al. 2009). Alternaria spp. and Penicillium sp., which were detected in fresh tissues (Table 3), can cause postharvest decay and produce mycotoxins on apple fruits (Escrivá et al. 2017; Moslem et al. 2013; Sutton et al. 2014; Wenneker and Kohl 2014). Because an ARISA is quite effective for detecting these fungi and for profiling microbial communities, it is useful for ecological studies of phylloplanes or phyllospheres (Shen et al. 2017).

\section{ACKNOWLEDGMENTS}

We sincerely thank Dr. S. Ikeda, Hokkaido Agricultural Research Center, National Agriculture and Food Research Organization, for his valuable information and guidance regarding the use of ARISA for fungal detection as well as for his technical advice. We thank Edanz (https://jp.edanz.com/ac) for editing a draft of this manuscript.

\section{LITERATURE CITED}

Akahira, T., Hanaoka, T., and Hirayama, K. 2016. Effects of several fungicides on apple bitter rot. Ann. Rept. Plant Prot. North Japan 67:140-145.

Andrews, J. H., Spear, R. N., and Nordheim, E. V. 2002. Population biology of Aureobasidium pullulans on apple leaf surfaces. Can. J. Microbiol. 48:500-513.

Brook, P. J. 1968. Pre-harvest lenticel spot of apples. New Zeal. J. Agric. Res. $11: 237-244$.
Cannon, P. F., Damm, U., Johnston, P.R., and Weir, B.S. 2012. Colletotrichum-Current status and future directions. Stud. Mycol. 73:181-213.

Casero, T., Benavides, A. L., and Recasens, I. 2009. Interrelation between fruit mineral content and pre-harvest calcium treatments on 'Golden Smoothee' apple quality. J. Plant Nutr. 33:27-37.

Chen, C., Verkley, G. J., Sun, G., Groenewald, J. Z., and Crous, P. W. 2016. Redefining common endophytes and pant pathogens in Neofabraea, Pezicula, and related genera. Fungal Biol. 120:1291-1322.

Ciesielski, S., Bulkowska, K., Dabrowska, D. Kaczmarczyk, D., Kowal, P., and Možejko, J. 2013. Ribosomal intergenic spacer analysis as a tool for monitoring methanogenic Archaea changes in an anaerobic digester. Curr. Microbiol. 67:240-248.

Damm, U., Cannon, P. F., Woudenberg, J. H. C., and Crous, P. W. 2012. The Colletotrichum acutatum species complex. Stud. Mycol. 73: 37-113.

Danovaro, R., Luna, G. M., Dell' Amnno, A., and Pietrangeli, B. 2006. Comparison of two fingerprinting techniques, terminal restriction fragment length polymorphism and automated ribosomal intergenic spacer analysis, for determination of bacterial diversity in aquatic environments. Appl. Environ. Microbiol. 72:5982-5989.

Escrivá, L., Oueslati, S., Font, G., and Manyes, L. 2017. Alternaria mycotoxins in food and feed: An overview. J. Food Qual. 40:1-20.

Ferguson, I. B., and Triggs, C. M. 1990. Sampling factors affecting the use of mineral analysis of apple fruit for the prediction of bitter pit. New Zeal. J. Crop Hort. Sci. 18:147-152.

Fisher, M. M., and Triplett, E. W. 1999. Automated approach for ribosomal intergenic spacer analysis of microbial diversity and ITS application to freshwater bacterial communities. Appl. Environ. Microbiol. 65: 4630-4636.

Gariepy, T. D., Andre Levesque, C. A., de Jong, S. N., and Rahe, J. E. 2003. Species specific identification of the Neofabraea pathogen complex associated with pome fruits using PCR and multiplex DNA amplification. Mycol. Res. 107:528-536.

Giraud, M., and Bompeix, G. 2012. Postharvest diseases of pome fruits in Europe: perspectives for integrated control. IOBC-WPRS Bulletin 84: 257-263.

Hansgate, A. M., Schloss, P. D., Hay, A. G., and Walker, L. P. 2005. Molecular characterization of fungal community dynamics in the initial stage of composting. FEMS Microbiol. Ecol. 51:209-214.

Hou, Y. M., Zhang, X., Zhang, N. N., Naklumpa, W., Zhao, W. Y., Liang, X. F., Zhang, R., Sun, G. Y., and Gleason, M. L. 2019. Genera Acremonium and Sarocladium cause brown spot on bagged apple fruit in China. Plant Dis. 103:1889-1901.

Ikeda, S., Fuji, S. Sato, T., Furuya, H., Naito, H., Ytow, N., Ezura, H., Minamisawa, K., and Fujimura, T. 2007. Microbial diversity in milled rice as revealed by ribosomal intergenic spacer analysis. Microbes Environ. 22:165-174.

Iwanami, Y., Kondo, K., and Iijima, A. 2003. Efficient tests for control of apple bitter rot. Ann. Rept. Kanto-Tosan Plant Prot. Soc. 50:65-69. (In Japanese).

Jami, E., Shterzer, N., and Mizrahi, I. 2014. Evaluation of automated ribosomal intergenic spacer analysis for bacterial fingerprinting of rumen microbiome compared to pyrosequencing technology. Pathogens 3: 109-120.

Johnson, R. D., Johnson, L., Kohmoto, K., Otani, H., Lane, C. R., and Kodama, M. 2000. A polymerase chain reaction-based method to specifically detect Alternaria alternata apple pathotype (A. mali), the causal agent of Alternaria blotch of apple. Phytopathology 90: 973-976.

Kawai, Y., Kondou, K., Okazawa, K., and Miyazawa, T. 2000. Distribution of apple bitter rot caused by Colletotrichum acutatum in Nagano Prefecture. Ann. Rept. Kanto-Tosan Plant Prot. Soc. 48:79-81. (In Japanese).

Lerner, A., Herschkovits, Y., Baudoin, E., Nazaret, S., Moenne-Leoccoz, Y., Okon, Y., and Jurkevitch, E. 2006. Effect of Azospirillum brasilense inoculation on rhizobacterial communities analyzed by denaturing gradient gel electrophoresis and automated ribosomal inter genic spacer analysis. Soil Biol. Biochem. 38:1212-1218.

Lin, H., Jiang, X., Yi, J., Wang, X., Zuo, R., Jiang, Z., Wang, W., and Zhou, E. 2018. Molecular identification of Neofabraea species associated with bull's-eye rot on apple using rolling-circle amplification of partial $E F-1 \alpha$ sequence. Can. J. Microbiol. 64:57-68.

Mari, M., Martini, C., Spadoni, A., Rouissi, W., and Bertolini, P. 2012. Biocontrol of apple postharvest decay by Aureobasidium pullulans. Postharvest Biol. Tec. 73:56-62.

Michalecka, M., Bryk, H., Poniatowska, A., and Pulawska, J. 2016. Identification of Neofabraea species causing bull's eye rot of apple in Poland and their direct detection in apple fruit using multiplex PCR. Plant Pathol. 65:643-654. 
Misawa, T., and Sato, T. 2013. Symptoms of diseases caused by Colletotrichum spp. found in various fruit crops in Hokkaido, Japan from 2008 to 2010 and characters of isolated Fungi. Ann. Rept. Plant Prot. North Japan 64:99-108. (In Japanese with English summary).

Moggia, C., and Yuri, J. A. 2003. Apple postharvest practices in Chile. Washington Tree Fruit Postharvest Conference. 2 and 3 Dec. 2003, Wenatchea, WA, USA, Proceedings: 1-9. https://www.researchgate.net/profile/ Claudia-Moggia/publication/251328571_APPLE_POSTHARVEST PRACTICES_IN_CHILE/links/53eb60ac0cf23b8116a9ba25/APPLEPOSTHARVEST-PRACTICES-IN-CHILE.pdf

Mosca, S., Nicosia1, M. G., Li, D., Cacciola, S. O., and Schena, L. 2014. Molecular analysis of Colletotrichum species in the carposphere and phyllosphere of olive. PLoS One 9:e114031.

Moslem, M. A., Yassin, M. A., El-Samawaty, A. E. M. A., Sayed, S. R. M., and Amer, O. E. 2013. Mycotoxin-producing penicillium species involved in apple blue mold. J. Pure Appl. Microbiol. 7:187-193.

Narita, T. 2005. Agricultural cooperative marketing and direct marketing of lower grade fruits: The case of the Tsugaru-Hiraka Agricultural Cooperative. Agric. Mark. J. Jpn. 14:1-10. (In Japanese with English summary).

Oberhänsli, T., Vorley, T., Tamm, L. and Schare, H. J. 2014. Development of a quantitative PCR for improved detection of Marssonina coronaria in field samples. Ecofruit. $16^{\text {th }}$ International Conference on Organic-Fruit Growing: 17-19 Feb. 2014, Hohenheim, Germany, Proceedings: 187-190.

Pancher, M., Ceol, M., Corneo, P. E., Longa, C. M. O., Yousaf, S., Pertot, I., and Campisano, A. 2012. Fungal endophytic communities in grapevines (Vitis vinifera L.) respond to crop management. Appl. Environ. Microbiol. 78:4308-4317.

Phytopathological Society of Japan, ed. 2021. Common Names of Plant Diseases in Japan. https://www.ppsj.org/pdf/mokuroku/mokuroku202109. pdf

Raese, J. T., and Drake, S. R. 2002. Calcium spray materials and fruit calcium concentrations influence apple quality. J. Am. Pomol. Soc. 56:136-143.

Ranjard, L., Poly, F., Lata, J. C., Mougel, C., Thioulouse, J., and Nazaret, S. 2001. Characterization of bacterial and fungal soil communities by automated ribosomal intergenic spacer analysis fingerprints: biological and methodological variability. Appl. Environ. Microbiol. 67:4479-4487.

Sato, T., and Moriwaki, J. 2009. Causal fungi of plant anthracnose (1). Microbiol. Cult. Coll. 25:27-32. (In Japanese).

Sato, Y. Hirayama, K., Toda, T., Nara, C., and Furuya, H. 2021. Previously unreported symptom of bull's-eye rot (Kigusare-byo) on apple fruits caused by Phlyctema vagabunda Desm. Jpn. J. Phytopathol. 87:133-145 (Japanese with English abstract).
Shen, Y., Nie, J., Li, Z., Li, H., Wu, Y., Don, Y., and Zhang, J. 2017. Differentiated surface fungal communities at point of harvest on apple fruits from rural and peri-urban orchards. Sci. Rep. 8:2165.

Singh, V., Gamrasni, D., Arie, R. B., Naschitz, S., and Friedman, H. 2016. Identification of open lenticels in apples after harvest in relation to lenticel breakdown development during storage. Postharvest Biol. Technol. 121:165-170.

Skidar, P., Okubara, P., Mazzola, M., and Xiao, C. L. 2014. Development of PCR assays for diagnosis and detection of the pathogens Phacidiopycnis washingtonesis and Sphaeropsis pyriputresdens in apple fruits. Plant Dis. 98:241-246.

Sutton, T. B., Aldwinckle, H. S., Agnello, A. M., and Walgenbach, J. F. (eds.) 2014. Compendium of Apple and Pear Diseases and Pests. 2nd ed. American Phytopathological Society Press, St. Paul, MN, USA.

Tsushima, Y., and Yukita, K. 2002. Isolates of apple bitter rot fungi collected from apple orchards in Aomori. Ann. Rept. Plant Prot. North Japan 53:118121. (In Japanese with English summary).

Vero, S., Garmendia, G., Gonzalez, M. B., Garat, M. F., and Wisniewski, M. 2009. Aureobasidium pullulans as a biocontrol agent of postharvest pathogens of apples in Uruguay. Biocontrol Sci. Technol. 19:1033-1049.

Wenneker, M. 2019. Fungal Pathogens in Pome Fruit Orchards and Causal Agents of Postharvest Decay. PhD thesis, Wageningen University, Wageningen, The Netherlands.

Wenneker, M., de Jong, P. F., Joosten, N. N., Goedhart, P. W., and Thomma, B. P. H. J. 2017. Development of a method for detection of latent European fruit tree canker (Neonectria ditissima) infections in apple and pear nurseries. Eur. J. Plant Pathol. 148:631-635.

Wenneker, M., and Kohl, J. 2014. Postharvest decay of apples and pears in the Netherlands. Acta Hort. 1053:107-111.

Woody, S. T., Spear, R. N., Nordheim, E. V., Ives, A. R., and Andrews, J. H. 2003. Single-leaf resolution of the temporal population dynamics of Aureobasidium pullulans on apple leaves. Appl. Environ. Microbiol. 69:4892-4900.

Xu, C., Zhang, H., Chi, F., Ji, Z., Dong, Q., Cao, K., and Zhou, Z. 2016. Species-specific PCR-based assays for identification and detection of Botryosphaeriaceae species causing stem blight on blueberry in China. J. Integr. Agric. 15:573-579.

Yokosawa, S., Eguchi, N., Kondo, K., and Sato, T. 2017. Phylogenetic relationship and fungicide sensitivity of members of the Colletotrichum gloeosporioides species complex from apple. J. Gen. Plant Pathol. 83: 291-298. 